\title{
In Vitro Comparative Assessment of Diffusion of ION from Calcium Hydroxide with Three Different Phytomedicine pastes through Dentin
}

\author{
${ }^{1}$ Manoj G Chandak, ${ }^{2}$ Richa R Modi, ${ }^{3}$ Bharat JJ Rathi, ${ }^{4}$ Rakesh J Gogiya, ${ }^{5}$ Purva Bhutada
}

\begin{abstract}
Aim: The main aim of the present study is in vitro assessment of the diffusion ability and degradation of calcium hydroxide from pastes prepared by using different vehicles to determine the influence of a vehicle on $\mathrm{pH}$ of calcium hydroxide $\left[\mathrm{Ca}(\mathrm{OH})_{2}\right]$ pastes.

Materials and methods: A total of 44 single-rooted premolar teeth were used in this study. The tooth crowns were removed and the root canals were prepared. Depending on the vehicle to be used for preparing calcium hydroxide pastes, four groups were made: group I: $\mathrm{Ca}(\mathrm{OH})_{2}$ saline paste (control group), group II: $\mathrm{Ca}(\mathrm{OH})_{2}$ neem , group III: $\mathrm{Ca}(\mathrm{OH})_{2}$ aloe vera , group IV: $\mathrm{Ca}(\mathrm{OH})_{2}$ turmeric paste. After biomechanical preparation, calcium hydroxide herbal paste dressings were applied and sealed with resin-based cement. The teeth were placed in containers with distilled water, and the $\mathrm{pH}$ of the water was measured at regular intervals over 3, 24, and 168 hours.
\end{abstract}

Results: The present study showed all herbal pastes allowed the diffusion of ions, but pastes prepared with aloe vera showed more ion diffusion and a marked increase in $\mathrm{pH}$, depicting better support for calcium hydroxide action.

Conclusion: Aloe vera allows better diffusion of calcium hydroxide through dentinal tubules, thus enhancing its action, and advises its use as a vehicle for placing intracanal medicament.

Clinical significance: Calcium hydroxide $\left[\mathrm{Ca}(\mathrm{OH})_{2}\right]$ is the most common and effective intracanal medicament. However, $\mathrm{CH}$ is not so effective when used alone. Therefore combinations are required to enhance its clinical properties. To be effective, diffusion of hydroxyl ions are required for which vehicle plays a significant role.

Keywords: Calcium hydroxide, Diffusion ability, Herbal pastes, ion diffusion, $\mathrm{Ph}$.

\footnotetext{
${ }^{1,4}$ Department of Conservative Dentistry and Endodontics, Sharad Pawar Dental College, Nagpur, Maharashtra, India

${ }^{2}$ Department of Conservative Dentistry and Endodontics, Sharad Pawar Dental College, Datta Meghe Institute of Medical Sciences,Sawangi,(M), Wardha, Maharashtra, India

${ }^{3}$ Department of Rasashastra and Bhaishajya Kalpana, Mahatma Gandhi Ayurvedic College, Hospital and Research Centre, DMIMS, Wardha, Maharashtra, India

${ }^{5}$ Department of Conservative Dentistry and Endodontics, Sharad Pawar Dental College, Wardha, Maharashtra, India

Corresponding Author: Richa R Modi, Department of Conservative Dentistry and Endodontics, Sharad Pawar Dental College, Datta Meghe Institute of Medical Sciences,Sawangi,(M), Wardha, Maharashtra, India, e-mail: richa.modi55@gmail.com
}

How to cite this article: Chandak MG, Modi RR, Rathi BJJ, Gogiya RJ, Bhutada P. In Vitro Comparative Assessment of Diffusion of ION from Calcium Hydroxide with Three Different Phytomedicine pastes through Dentin. World J Dent 2018;9(5):366-371.

\section{Source of support: Nil}

\section{Conflict of interest: None}

\section{INTRODUCTION}

Calcium hydroxide $\left[\mathrm{Ca}(\mathrm{OH})_{2}\right]$ is commonly used for its antimicrobial ability. It helps to dissolve organic tissues, and the capacity to inactivate bacterial endotoxins . ${ }^{1}$

Its mechanism of actions is achieved through the ionic dissociation of $\mathrm{Ca}^{(2+)}$ and $\mathrm{OH}^{(-)}$ions. It causes reduced capillary permeability and thus reduced serum flow. This leads to a reduction in inhibitory pyrophosphate, which causes mineralization. ${ }^{2} \mathrm{Ca}(\mathrm{OH})_{2}$ is a multipurpose agent and has many uses in dentistry such as pulp capping, apexification, endodontic sealer and as a perforation repair material. ${ }^{3}$

C. longa belongs to the Zingiberaceae family. It has a wide spectrum of activities such as anti-inflammatory, antiviral, antiprotozoal, antibacterial, antioxidant, antifungal. The main yellow bioactive component of C.longa is curcumin.

Azadirachta indica is also known as "Indian Neem." It mainly works on an anti-adherence property. It alters bacterial cell adhesion and affects their colonizing ability. It has got antioxidant properties. It has significant antimicrobial activity against E. faecalis and C. albicans. Azadirachtin is a secondary metabolite present in the seeds of the neem tree. It acts mainly as antifeedant and growth disruptor. ${ }^{4}$

Aloe Barbadensis miller which is also known as aloe vera is a potentially effective herb. Aloe vera contains vitamins, enzymes, minerals, sugars, lignin, saponins, salicylic acids, and amino acids.

The study aims is to compare the diffusibility of ions via dentinal tubules of three different $\mathrm{Ca}(\mathrm{OH})_{2}$ containing herbal pastes and compare it with the $\mathrm{Ca}(\mathrm{OH})_{2}$ paste with saline.

The objectives of the study were to evaluate the diffusibility of ions through dentinal tubules of $\mathrm{Ca}(\mathrm{OH})_{2}$-saline paste, and other herbal pastes mixed with $\mathrm{Ca}(\mathrm{OH})_{2}$. 


\section{AIM}

The study aims is to compare the diffusion ability of ions through dentinal tubules of three different $\mathrm{Ca}(\mathrm{OH})_{2}$ containing herbal pastes and compare it with the $\mathrm{Ca}(\mathrm{OH})_{2}$ paste with saline.

\section{MATERIALS AND METHODS}

The study was done on 44 single-rooted extracted premolars with the following criteria:

\section{Inclusion Criteria}

- Single-rooted premolar teeth.

- Teeth with no gross caries.

- Teeth having patent canals.

\section{Exclusion Criteria}

- Teeth with gross deviation in their normal anatomy.

- Teeth with internal and external resorption.

- Teeth having fractured roots or calcification within the canal system.

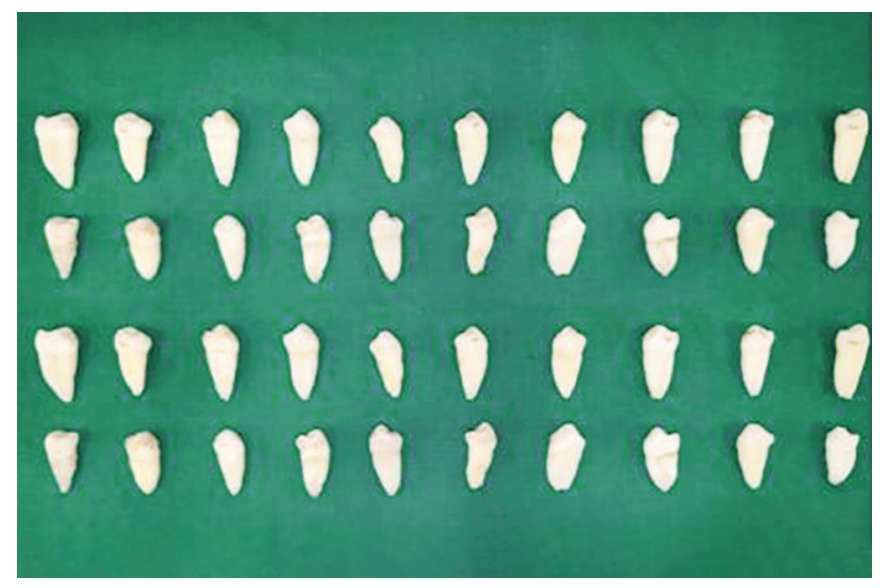

Fig. 1: Specimen of extracted single rooted teeth

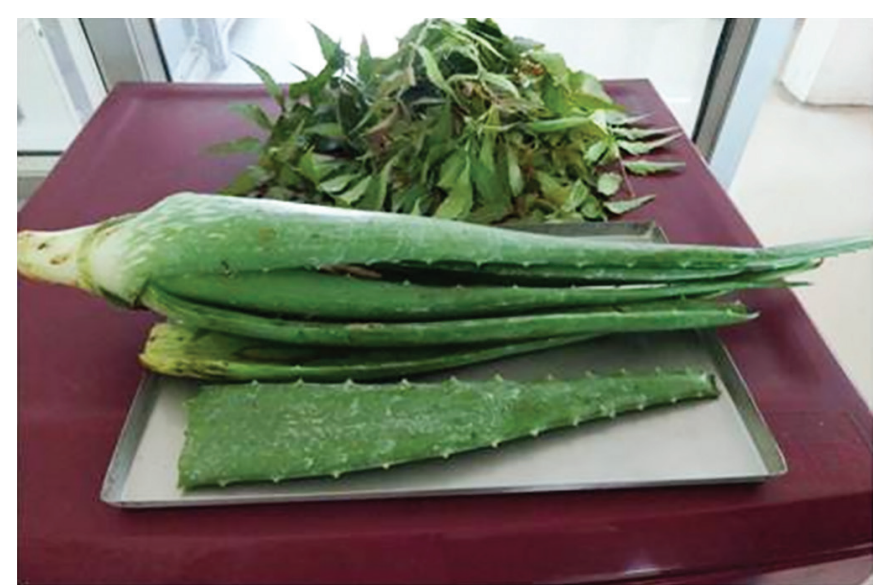

Fig. 3: Freshly obtained aloe vera leaves and neem leaves

\section{Equipments}

pH meter (digital-1010 Esico, India)

\section{Preparation of Sample}

\section{Specimen preparation}

Forty freshly extracted teeth (Fig. 1) were cleaned and stored as per the guidelines. Teeth were decoronated using a carborundum disc at the cementoenamel junction (Fig. 2). Working length was determined, and the canal was prepared till \#40 $\mathrm{k}$ file. The root canals were irrigated with distilled water throughout the instrumentation procedure with a $2 \mathrm{~mL}$ disposable syringe. After this period, the root canals were rinsed with saline solution and dried with absorbent paper points.

Based on the vehicle used for preparing $\mathrm{Ca}(\mathrm{OH})^{2}$ pastes, four groups are made:

Group 1: $\mathrm{Ca}(\mathrm{OH})_{2}$-saline paste (formed by mixing $1 \mathrm{gm}$ of $\mathrm{CaOH}$ with $1 \mathrm{~mL}$ of saline).

Group 2: $\mathrm{Ca}(\mathrm{OH})_{2}$-Neem Paste (formed by mixing $1 \mathrm{gm}$ of $\mathrm{CaOH}$ with $1 \mathrm{~mL}$ of neem extract) (Fig. 3).

Group 3: $\mathrm{Ca}(\mathrm{OH})_{2}$-aloe vera paste (formed by mixing $1 \mathrm{gm}$ of $\mathrm{Ca} \mathrm{OH}$ with $1 \mathrm{~mL}$ of aloe vera extract) (Fig. 4).

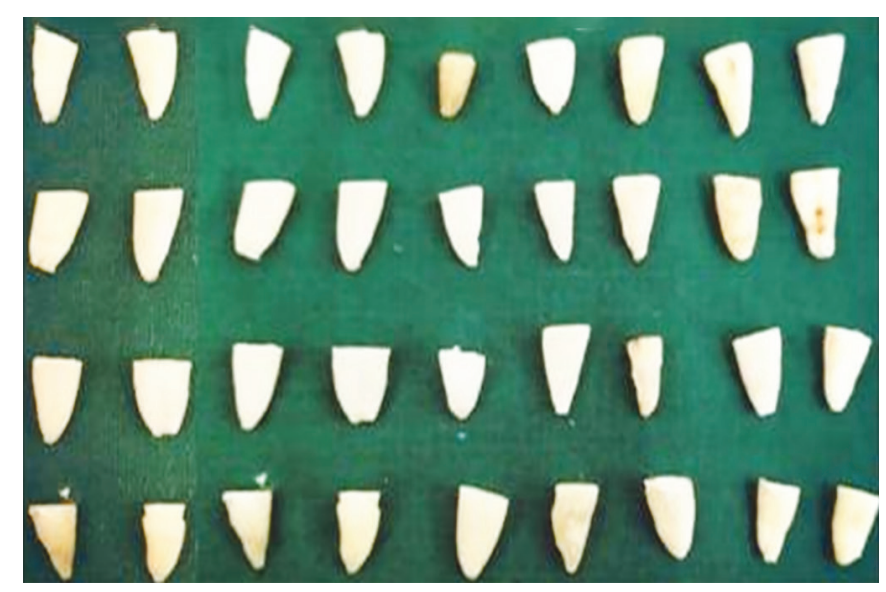

Fig. 2: Decoronation of teeth at cemento enamel junction

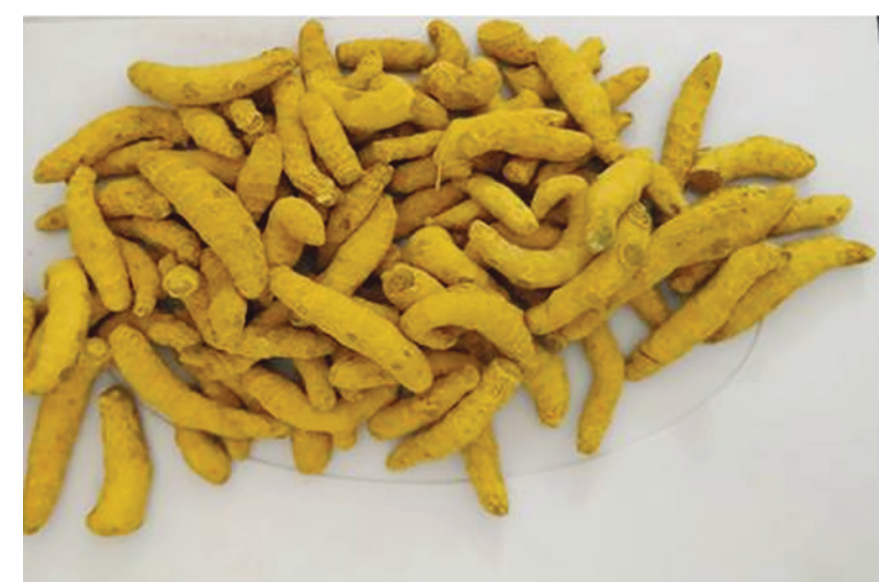

Fig. 4: Turmeric roots which were grinded to powder 
Group 4: $\mathrm{Ca}(\mathrm{OH})_{2}$-turmeric paste (formed by mixing $1 \mathrm{gm}$ of $\mathrm{CaOH}$ with $1 \mathrm{~mL}$ of turmeric paste) (Fig. 4)

After biomechanical preparation, above prepared intracanal medicaments were placed inside canal and sealed with cement (resin based). The teeth were then transferred in sections containing distilled water. The $\mathrm{pH}$ of the water was measured at regular intervals over 3,24 , and 168 hours using $\mathrm{pH}$ meter.

\section{RESULTS}

Table 1 shows that highest $\mathrm{pH}$ scores were in $\mathrm{Ca}(\mathrm{OH}) 2$ plus aloe vera intracanal medicament group $(7.41 \pm 0.33)$ followed by turmeric group $(7.09 \pm 0.23)$, followed by Neem group $(6.9 \pm 0.12)$ and the least $\mathrm{pH}$ was seen in saline plus $\mathrm{Ca}(\mathrm{OH}) 2$ $(6.73 \pm 0.16)$ and all these differences in the values were significant statistically by one way ANOVA $(\mathrm{p}<0.05)$. By comparing these groups as shown in Graph 1, by post-hoc analysis, it was observed that there was a significant difference between group 1 with group 2 and 3 and insignificant between group 1 with group 4 . Similarly, a significant difference was found between group 2 with group 3 and 4 .

Table 2 shows that highest $\mathrm{pH}$ scores were in $\mathrm{Ca}(\mathrm{OH})_{2}$ plus aloevera intracanal medicament group $(7.86 \pm 0.07)$ followed by Neem group $(7.38 \pm 0.08)$ followed by turmeric group $(7.37 \pm 0.03)$, and the least $\mathrm{pH}$ was seen in saline plus $\mathrm{Ca}(\mathrm{OH})_{2}(6.61 \pm 0.02)$ and all these differences in the values were significant statistically by one way ANOVA ( $p<0.05)$. By comparing these groups, as shown in Graph 2, by post-hoc analysis it was observed that there was a significant difference between group 1 with group 2 and 3 and insignificant between groups 3 with group 4. Similarly, a significant difference was found between group 2 with groups 3 and 4 .

Table 3 shows that highest $\mathrm{pH}$ scores were in $\mathrm{Ca}(\mathrm{OH})_{2}$ plus aloe vera intracanal medicament group $(7.88 \pm 0.03)$ followed by turmeric group $(7.35 \pm 0.05)$, followed by neem group $(7.13 \pm 0.07)$ and the least $\mathrm{pH}$ was seen in saline plus $\mathrm{Ca}(\mathrm{OH})_{2}(6.29 \pm 0.07)$ and all these differences in the values were significant statistically by one way ANOVA $(p<0.05)$. By comparing these groups as shown in Graph 3, by post-hoc analysis it was observed that there was a significant difference between group 1 with groups 2 and 3. Similarly, a significant difference was found between group 2 with groups 3 and 4 . And the insignificant difference was found between group 3 and 4 .

Table 1: Comparison of mean $\mathrm{pH}$ scores at 3 hours using one way ANOVA

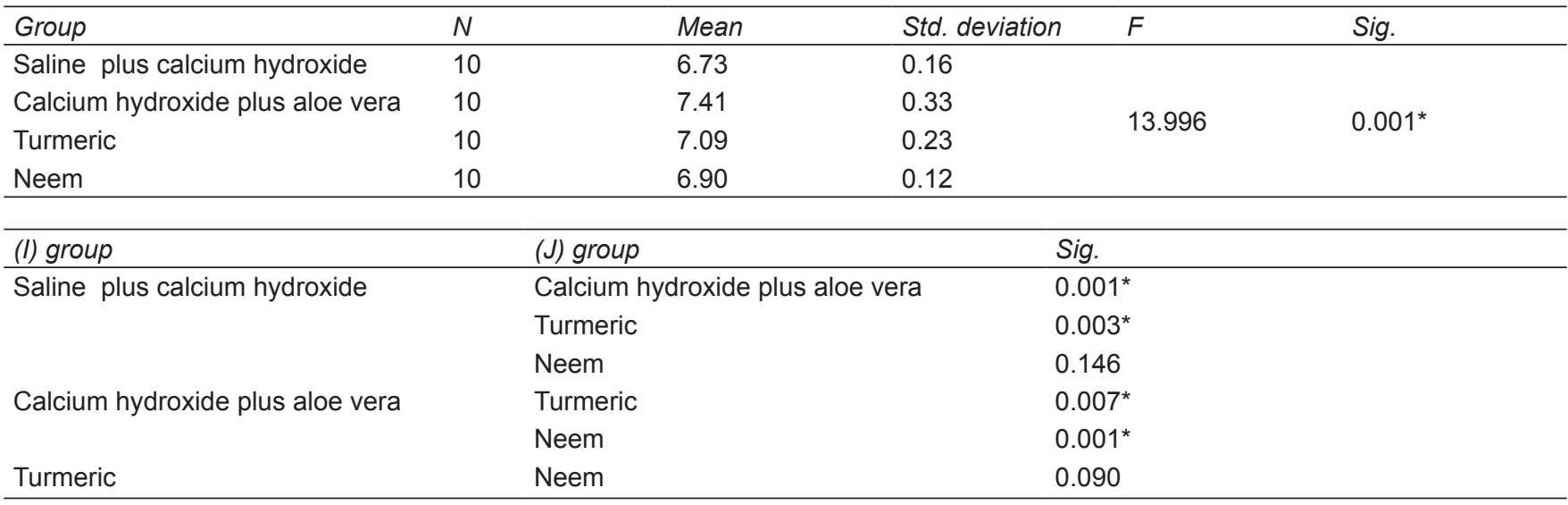

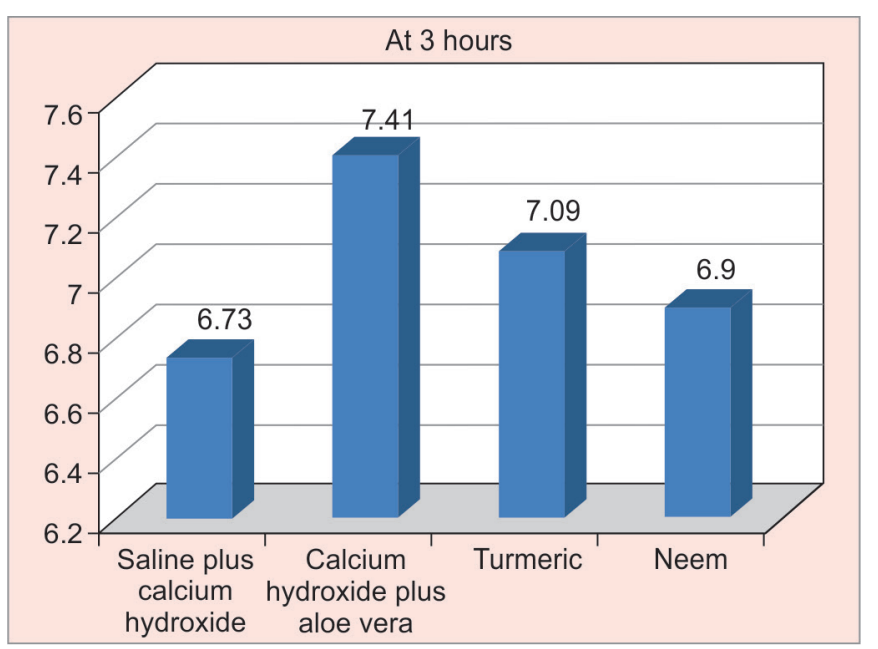

Graph 1: $\mathrm{pH}$ at 3 hours 
Table 2: Comparison of mean pH scores at 24 hours using one way ANOVA

\begin{tabular}{lllllll}
\hline Time interval & Group & $N$ & Mean & Std. deviation & F & Sig. \\
\hline \multirow{4}{*}{24} & Saline plus calcium hydroxide & 10 & 6.61 & 0.02 & & \\
& Calcium hydroxide plus aloe vera & 10 & 7.86 & 0.07 & 708.623 & $0.001^{*}$ \\
& Turmeric & 10 & 7.37 & 0.03 & & \\
& Neem & 10 & 7.38 & 0.08 & & \\
\hline
\end{tabular}

\begin{tabular}{llll}
\hline Dependent variable & (I) group & (J) group & Sig. \\
\hline & & Calcium hydroxide plus aloe vera & $0.001^{*}$ \\
& Saline plus calcium hydroxide & Turmeric & $0.001^{*}$ \\
24 & & Neem & $0.001^{*}$ \\
& & Turmeric & $0.001^{*}$ \\
& Calcium hydroxide plus aloe vera & Neem & $0.001^{*}$ \\
& Turmeric & Neem & 0.529 \\
\hline
\end{tabular}

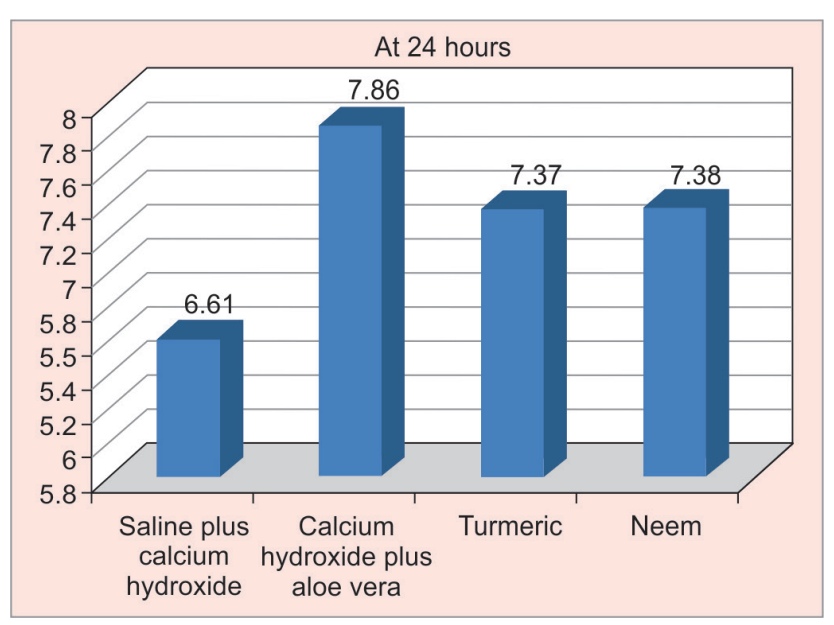

Graph 2: $\mathrm{pH}$ at 24 hours

Table 3: Comparison of mean pH scores at 168 hours using one way ANOVA

\begin{tabular}{lllllll}
\hline Time interval & Group & $N$ & Mean & Std. Deviation & F & Sig. \\
\hline \multirow{4}{*}{168} & Saline plus calcium hydroxide & 10 & 6.29 & 0.07 & & \multirow{2}{*}{$0.001^{*}$} \\
& Calcium hydroxide plus aloe vera & 10 & 7.88 & 0.03 & 937.736 \\
& Turmeric & 10 & 7.28 & 0.05 & & \\
& Neem & 10 & 7.22 & 0.07 & \\
\hline
\end{tabular}

\begin{tabular}{llll}
\hline Dependent Variable & (I) group & (J) group & Sig. \\
\hline & & Calcium hydroxide plus aloe vera & $0.001^{*}$ \\
& Saline plus calcium hydroxide & Turmeric & $0.001^{*}$ \\
24 & & Neem & $0.001^{*}$ \\
& & Turmeric & $0.001^{*}$ \\
& Calcium hydroxide plus aloe vera & Neem & $0.001^{*}$ \\
& Turmeric & Neem & 0.034 \\
\hline
\end{tabular}

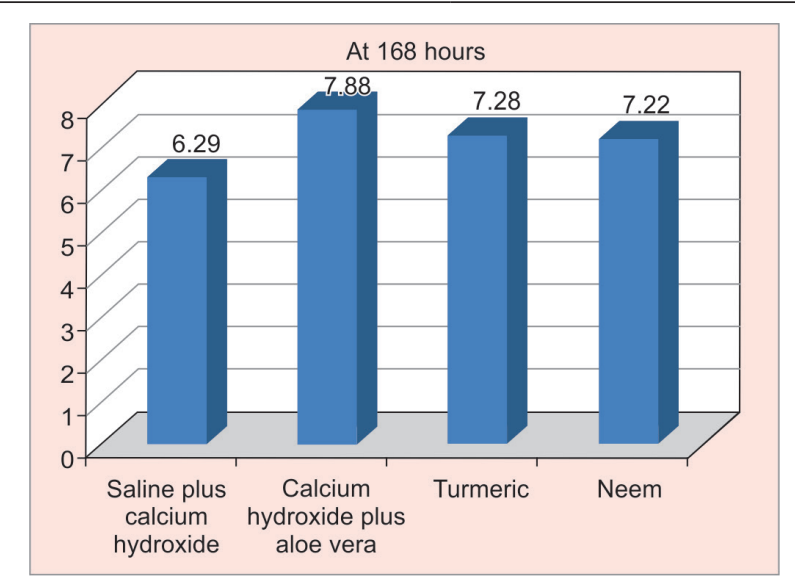

Graph 3: pH at 168 hours 


\section{DISCUSSION}

The study purposes to explore the herbal medicaments in endodontics. Since the microorganisms develop resistance against conventional drugs and medicaments, invent of herbs against root canal pathogens is imperative.

The methodology used in this study is very simple, and the types of equipment used are also easily accessible. $\mathrm{Ca}(\mathrm{OH})_{2}$ dissociates into hydroxyl ions and makes alkaline $\mathrm{pH}$. Dentin has a buffering action. Therefore a change in $\mathrm{pH}$ can be an effective measure to identify the diffusing ability of different intracanal medicaments.

Successful endodontic therapy is based on complete root canal disinfection. An aqueous solution was used in the present study. Herbal preparations are used in the present science due to the presence of phytochemicals.

Elimination of microorganisms cannot be achieved by single technique or use of a single material. This warrants the use of intracanal medicament along with intracanal irrigation. ${ }^{5}$

The ideal requirements of the intracanal medicament include ability to diffuse through dentinal tubules, biocompatibility, and if possible hard tissue repair.

$\mathrm{Ca}(\mathrm{OH})_{2}$ is the main root canal medicament used in endodontics. It is a white, odorless powder, with low solubility in water, insolubility in alcohol, and a high $\mathrm{pH}$. It has extended clinical action. It is antimicrobial and has anti-inflammatory activity. ${ }^{6}$ It activates the alkaline phosphatase enzyme, which induces mineralized tissue formation and acts in the repair process. For its diffusion into dentinal tubules, it requires an adequate vehicle.

$\mathrm{Ca}(\mathrm{OH})_{2}$ is highly alkaline and encourages repair and dentinal bridge formation. Its antimicrobial activities are due to their high $\mathrm{pH}$ which neutralizes lactic acids from osteoclasts. $\mathrm{Ca}(\mathrm{OH})_{2}$-based pastes depends on diffusion of hydroxyl ions which maintains the $\mathrm{pH}$. $\mathrm{Ca}(\mathrm{OH})_{2}$ dissociates into $\mathrm{OH}^{-}$and $\mathrm{Ca}^{2+}$ ions. This is dependent on the vehicle used to form $\mathrm{Ca}(\mathrm{OH})_{2}$ pastes. The mixture paste should allow slow diffusion of ions for the action of $\mathrm{Ca}(\mathrm{OH})_{2}$.

The success of $\mathrm{Ca}(\mathrm{OH})_{2}$ paste as a root canal dressing is related to its dissociation into calcium and hydroxyl ions. ${ }^{7}$ For the $\mathrm{Ca}(\mathrm{OH})_{2}$ to insert its action, it is important that it diffuses in the dentin and remain in pulp tissues in a sufficient concentration to produce the $\mathrm{pH}$ level required to destruct bacteria of interests.

Abidin et al. described that the mechanism of action of an intracanal medicament made from natural extracts was predominantly on the cell membrane by disrupting its structure, blocking membrane synthesis, and inhibition of cellular respiration thereby causing cell leakage and cell death. ${ }^{8}$ An ideal intracanal medicament should possess maximal antimicrobial and tissue solving properties and minimal toxic effects.
E. faecalis is a gram-positive and a facultative anaerobe. It is highly associated with secondary and persistent infections. Its prevalence ranges from 24 to $77 \%$. E. faecalis develop resistance, therefore there is a strong need to find alternatives which can totally eliminate the culprit microorganisms. $\mathrm{Ca}(\mathrm{OH})_{2}$ alters the bacterial lipopolysaccharides in the cell wall due to its high $\mathrm{pH}$. However, it has been shown to be ineffective at killing E. faecalis as this high $\mathrm{pH}$ is not maintained. ${ }^{9}$

Neem has been extensively used in Ayurveda. Its active ingredient is nimbidin. From nimbidin other active constituents like nimbolide and nimbidic acids are extracted. Neem is a rich source of antioxidants. It has got antimicrobial property against $S$. mutans and E. faecalis. Neem has antimicrobial properties due to the presence of alkaloids, glycosides, flavonoids, steroids, anthraquinone and tannic acid. These active ingredients uncouple mitochondrial oxidative-phosphorylation; thus, inhibiting the respiratory chain. This leads to the anti-adherence activity which interrupts with bacterial adhesion. ${ }^{10}$

Aloe vera gel or mucilage has got many therapeutic purposes. Its active constituents are glycosides, saponins, flavonoids, and steroids. These active constituents uncouple mitochondrial oxidative phosphorylation, thus inhibiting the respiratory chain. It does that by altering the microbial adhesion. It reduces the adhesion in dentistry. It has got significant action against E. faecalis. The six antiseptic agents of Aloe vera are sulfur; lupeol, salicylic acid, urea nitrogen; cinnamic acid and phenols. Polysaccharides contained in the gel of the leaves promote wound healing. It contains protein, minerals, carbohydrates, and moisture. It has anti-inflammatory activities. It is a potent antioxidant. It is effective against $E$. faecalis. Its advantages are ease of availability and cost-effectiveness.

Since commercially available intracanal medicaments have a various cytotoxic effect, attention has been shifted to extract medicine from plants. ${ }^{11}$ Curcumin longa has benefits in treating dental chronic infection and inflammation diseases. ${ }^{12}$

$\mathrm{Ca}(\mathrm{OH})_{2}$ has shown to provide more bacterial free canal than the canal with no dressing. However, $\mathrm{Ca}(\mathrm{OH})_{2}$ alone cannot eradicate all the bacteria present in the root canal. E. faecalis colonizes the main canal as well as the lateral and accessory canals. ${ }^{13}$ High ph value supplies more hydroxyl ions which are fatal to a wide variety of microorganisms. $\mathrm{Ca}(\mathrm{OH})_{2}$ has got various applications in dentistry such as inter appointment to flare up cases, pulp capping agent and root canal sealers. However, $\mathrm{Ca}(\mathrm{OH})_{2}$ cannot remove all the species of bacteria present in the root canal. ${ }^{14}$ They all have an inhibitory action on fungi, bacteria, and viruses. $\mathrm{Ca}(\mathrm{OH})_{2}$ can suppress the Enterococcus faecalis present in the root canal which 
suppresses the lymphocytes and thus leads to failure. ${ }^{15}$ Herbal preparations are used in the present science due to the presence of phytochemical present in studies. The result of the study revealed that in 3, 24 and 168 hours, aloe vera plus $\mathrm{Ca}(\mathrm{OH})_{2}$ paste showed the highest $\mathrm{pH}$ while $\mathrm{Ca}(\mathrm{OH})_{2}$ plus saline showed the least $\mathrm{pH}$. The diffusion ability of aloe vera at 3, 24 and 168 hours is more than that of turmeric, neem and $\mathrm{Ca}(\mathrm{OH})_{2}$ pastes.

\section{CONCLUSION}

Plants are a major source of new chemicals and raw materials. It can contribute a lot to the pharmaceutical industry in near future. The major benefit of herbs is its low toxicity, easy availability, increased shelf life, cost-effectiveness. In vitro experiments shows promising results for herbs but preclinical and clinical trials are further needed to guarantee its usage. Biocompatibility and safety factor of the herbs need to be evaluated before concluding herbs as an alternative to synthetic medicaments.

Taking into considerations the limitations of in vitro study, the present study can be concluded that aloe vera allowed better diffusion of $\mathrm{Ca}(\mathrm{OH})_{2}$ through dentinal tubules, thus enhancing its action, and advise its use as a vehicle for placing intracanal medicament.

\section{CLINICAL SIGNIFICANCE}

Bacteria have a major role in the initiation, progression, and etiology of pulp and periradicular diseases. Intracanal medication has a pivotal role in the success of endodontic treatment and elimination of infection along with chemomechanical preparation.

$\mathrm{Ca}(\mathrm{OH})_{2}$ is the most common and effective intracanal medicament. However, $\mathrm{CH}$ is not so effective when used alone. Therefore combinations are required to enhance its clinical properties. To be effective, diffusion of hydroxyl ions are required for which vehicle plays a significant role.

\section{REFERENCES}

1. Dausage P, Dhirawani RB, Marya J, Dhirawani V, Kumar V. A Comparative Study of Ion Diffusion from Calcium Hydroxide with Various Herbal Pastes through Dentin. International journal of clinical pediatric dentistry. 2017 Jan;10(1):41.

2. Farhad A, Mohammadi Z. Calcium hydroxide: a review. Int Dent J. 2005 Oct;55(5):293-301.

3. Dutta B, Dhull KS, Das D, Samir PV, Verma RK, Singh N.Evaluation of Antimicrobial Efficacy of various Intracanal Medicaments in Primary Teeth: An in vivo Study. Int J Clin Pediatr Dent. 2017;10(3):267-271.

4. Batista VE de S, Olian DD, Mori GG. Diffusion of hydroxyl ions from calcium hydroxide and Aloe vera pastes. Braz Dent J. 2014;25(3):212-216.

5. Montero JC, Mori GG. Assessment of ion diffusion from a calcium hydroxide-propolis paste through dentin. Braz Oral Res. 2012 Aug;26(4):318-322.

6. Antibacterial action of calcium hydroxide vehicles and calcium hydroxide pastes. - PubMed - NCBI [Internet]. [cited 2017 Nov 15]. Available from: https://www.ncbi.nlm.nih. gov/pubmed/23129141

7. Pacios MG, de la Casa ML, de Bulacio M los A, López ME. Influence of different vehicles on the $\mathrm{pH}$ of calcium hydroxide pastes. J Oral Sci. 2004 Jun;46(2):107-111.

8. Raghavendra SS, Balsaraf KD. Antifungal efficacy of Azadirachta indica (neem) - An in vitro study. Brazilian Journal of Oral Sciences. 2014 Oct 1;13:242-245.

9. Haapasalo HK, Sirén EK, Waltimo TM, Orstavik D, Haapasalo MP. Inactivation of local root canal medicaments by dentine: an in vitro study. International Endodontic Journal. 2000 Mar;33(2):126-131.

10. Porkaew P, Retief DH, Barfield RD, Lacefield WR, Soong SJ. Effects of calcium hydroxide paste as an intracanal medicament on apical seal. J Endod. 1990 Aug;16(8):369-374.

11. Noushad MC, Balan B, Basheer S, Usman SB, Askar MM. Antimicrobial efficacy of different natural extracts against persistent root canal pathogens: An In vitro study. Contemporary clinical dentistry. 2018 Apr;9(2):177.

12. Saha S, Nair R, Asrani H. Comparative Evaluation of Propolis, Metronidazole with Chlorhexidine, Calcium Hydroxide and Curcuma Longa Extract as Intracanal Medicament Against E.faecalis- An Invitro Study. J Clin Diagn Res. 2015 Nov;9(11):ZC19-21.

13. Stuart CH, Schwartz SA, Beeson TJ, Owatz CB. Enterococcus faecalis: its role in root canal treatment failure and current concepts in retreatment. Journal of endodontics. 2006 Feb 1;32(2):93-98.

14. Siqueira Jr JF, Lopes HP. Mechanisms of antimicrobial activity of calcium hydroxide: a critical review. International endodontic journal. 1999 Sep;32(5):361-369.

15. Mohammadi Z, Dummer PM. Properties and applications of calcium hydroxide in endodontics and dental traumatology. International endodontic journal. 2011 Aug;44(8):697-730. 